\title{
Will Rising Debt in China Lead to a Hard Landing?
}

\author{
Wang Man Cang ${ }^{1} \&$ Zhou Ming Matt ${ }^{1}$ \\ ${ }^{1}$ School of Economics and Management, Northwest University, Xi-an, China \\ Correspondence: Wang Man Cang, School of Economics and Management, Northwest University, Xi-an 710127, \\ China. Tel: 86-29-8830-8062. E-mail: wang-mc@126.com \\ Received: June 28, 2017 \\ Accepted: July 14, 2017 \\ Online Published: August 10, 2017 \\ doi:10.5539/ijef.v9n9p60 \\ URL: https://doi.org/10.5539/ijef.v9n9p60
}

\begin{abstract}
Moody has recently downgraded China's sovereign debt, which's Moody's first downgrade for the country since 1989. The objective of this study is to get an insight into the local and regional government debt in China, analyze the key factors, and evaluate the economic risks. Based on the published data since 1996, the granger causality test is performed to find out the relationship between local government debt level, the fiscal income, GDP growth rate and CPI. Some major findings are: i) local government debt is accumulated through more spending on economic development and less funding obtained from the revenue sharing scheme between governments. ii) fiscal income and GDP growth rate have positive impact on the increase of local government debt. iii) CPI increase shows negative impact on the local government debt. It's projected that in the coming years, slower growth and less income with a stable CPI could slow down debt accumulation. The Chinese government should monitor the risk factors closely and use risk mitigation tools to avoid a hard landing.
\end{abstract}

Keywords: government debt, China, GDP growth rate, economic risk, hard landing

\section{Introduction}

\subsection{Background}

There has been wide concerns that slowing growth and rising debts will weaken the financial strength of the world's second largest economy. On May 24, Moody's Investors Service downgraded China's long-term local currency and foreign currency issuer ratings from Aa3 to A1. The last time Moody cut China's credit rating was 1989 when the Tiananmen Square protests occurred. According to the statement issued by the rating agency, it's expected that China's financial strength will erode with economy-wide debt continues to rise as potential growth slows.

Alfred Schipke, the IMF's senior resident representative, has also suggested that the rising debt issue in China is posing high risks for the economy, especially as the country has an increasingly large, leveraged and interconnected financial system.

According to the report by the Bank for International Settlements (BIS), China has the largest credit-to-GDP gap among all reporting countries for Q1 2016. Figure 1 displays that the credit-to-GDP ratios for China and other countries from Q1 1999 to Q1 2016. The credit-to-GDP ratio measures the credit from All sectors to Private non-financial sector in term of the percentage to the GDP. Emerging market economies such as Brazil, Russia and India usually have the credit-to-GDP ratios below $80 \%$ through the years. The advanced economies such as US, Japan and European countries have the ratios over $100 \%$ with the downward trend since 2009. In contrast, China has had a sharp increase since 2009 and reached 209.8\% in Q1 2016, which is the highest of all the countries listed above. 


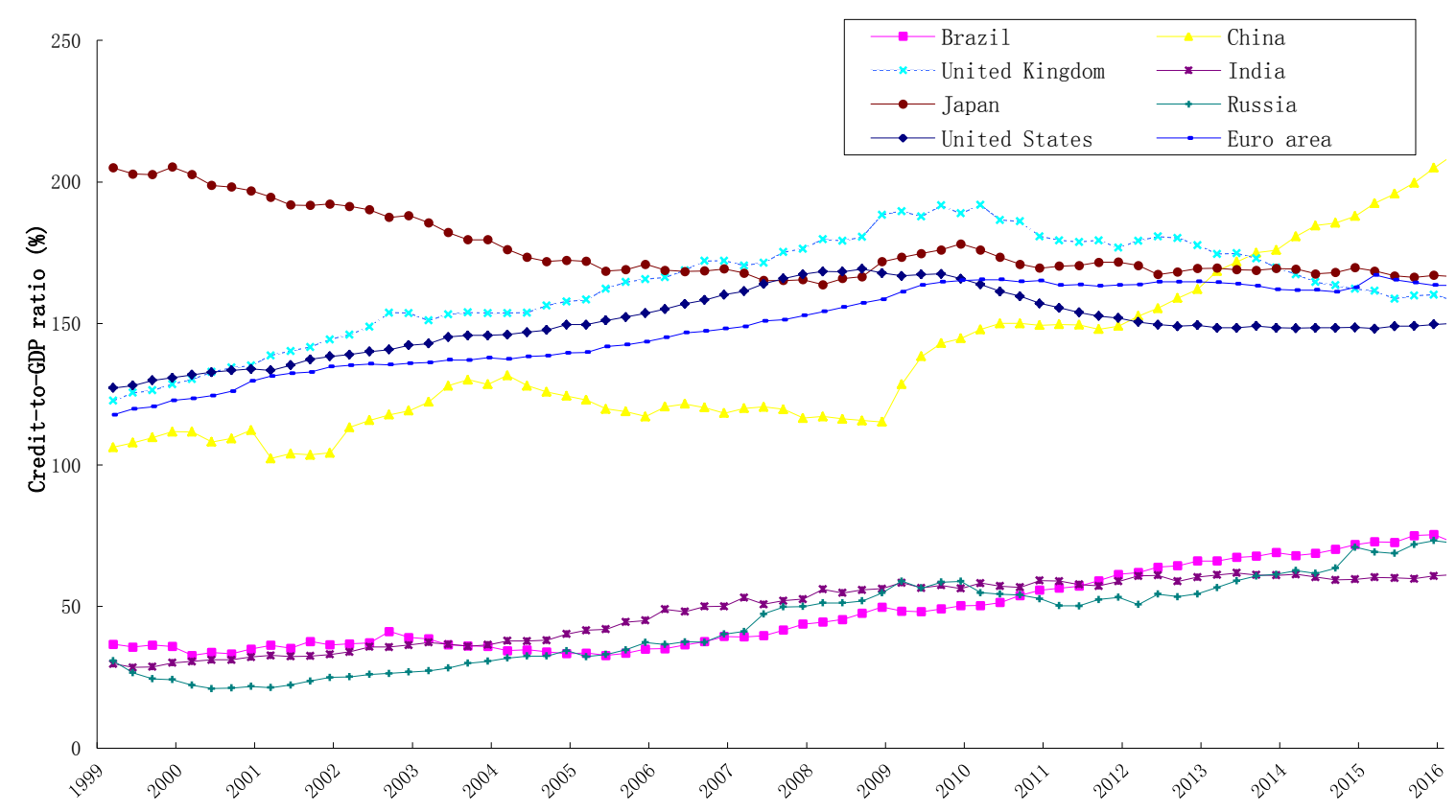

Figure 1. Credit-to-GDP ratios for China and other countries from 1999 to 2016

Note. China has the largest credit-to-GDP ratio since 2014 and reached 209.8\% for Q1 2016.

\subsection{Problem of Excessive Debt}

Recent history provides excellent examples that excessive debt has serious impact on the economy. Ranking as the top 10 city in US, Detroit became the largest US city to file the bankruptcy with the debt of $\$ 18$ billion on July 18 2013. After multiple years of deficits, its crime rate surged into five times the national average and unemployment rate jumped to $18.3 \%$. In Europe, Greece became the first developed country that failed to make an IMF loan repayment with the debt of $€ 323$ billion on June 30 2015. The average wage fell about $20 \%$ and unemployment rose to nearly $25 \%$.

China's economy has grown enormously in the past three decades with the annualized GDP growth rate of over $8 \%$ each year. It's reasonable to assume that the huge amount of economic development is fueled by significant public financing efforts including all levels of government debt in China. According to the survey conducted by the national audit office in 2013, it's reported that by the end of June, government debts had reached a total of 30 trillion Yuan ( $\$ 4.78$ trillion), or about $130 \%$ of the annual income. 59\% of the government debts were owned by the local governments, among which 36 local governments owning an average of $\$ 17.4$ billion each, roughly the same size of debt with Detroit.

\subsection{Literature Review}

Economists have long discussed about policy making regarding to the government debt and economic growth. Orszag, Rubin, and Sinai (2004) made the claim that rising debt levels could alert investors and cause interest rates to spike so that higher return can be guaranteed for investors to keep financing the debt. The interest rate spike would lead to financial market disturbance or "disarray". Manasse and Roubini (2005) have reviewed the academic literature on sovereign debt defaults and found that exposure to currency risk dominates the probability of debt default or financial crisis. More recently, Carment Reinhart and Kenneth Rogoff have analyzed the Growth in a Time of Debt (GITD) issue based on the economic data from dozens of countries and across hundred of years. The conclusion in their book, "The Time is Different: Eight Centuries of Financial Folly" (2009), is that the economic growth will be hindered when the government debt to GDP or the so-called threshold debt level is over $90 \%$ while there is no necessary effect on growth at lower levels of debt.

The threshold debt level has been in a heated debate. Afonso and Jalles (2013) pointed out errors in the Reinhart-Rogoff estimation methodology. Pescatori et al. (2014) developed econometric models to test the existence of a threshold debt level. More importantly, Jonh Irons and Josh Bivens (2010) have studied the United States economy data and argued that there's no compelling reason to state that the GITD "90\% threshold" for gross government debt would lead to a slower growth, and hence should not be used as a guideline for U.S. fiscal 
policy. They have found that U.S. has only exceeded the $90 \%$ threshold in six of the 218 years, all of them are in the 1940s WWII period. And if removing the defense spending contributions the GDP growth is nearly double that of the low-debt years. Modern economies such as the United States can borrow in own currency and have independent monetary and exchange rate policies, using the simple ratio of public debt to GDP as a predictor variable is not wise as the situation is different comparing with the other countries through time.

However, few empirical study on government debt and economic growth in China has been reported, in particular regard to the LGD. Zhang Li (2011) claimed that rising LGDs are partially resulted from the the local government official promotion mechanism, the officials tend to raise debts for infrastructure investment and better performance evaluation. Fan Jiangyong and Mo Jiawei (2014) warned that the increasing level of LGDs would lead to higher housing cost and serious risks to the economy. On the other hand, Wu Yanrui (2014) examined the impact of LGD based on collected data and held an optimistic view given the level of government debt in China was much lower than those observed in OECD economies. The Financial Research Institute of Chinese Academy of Social Sciences (2015) released the Chinese government balance sheet report, which stated the total assets of 111.8 trillion yuan and the total liabilities of 56 trillion yuan at the end of 2013. Hence the risk was low.

From the above discussion, we can say that the research conducted on the issue of debt sustainability in the China context have majorly focused on the benefits for the local governments to raise debt rather than seeking out reasons on fiscal income. Further, there's lack of study on the contributing factors based on the time series. Therefore, our study tries to fill this research gap by analyzing the contributing factors to local government debt and evaluate the financial risks in trends using the granger causality test method.

This paper aims to explain the factors contributing to the local government debt in China with empirical study on the economic development data. It is probably the first empirical paper to analyze the rising debt issue with the discussion of China's new normal of slower growth and structural change. Policy implications are discussed, and the concluding remarks are presented at end.

\section{Data and Methodology}

The central and local governments in China have been sharing the tax revenues based on the centralized financial budgeting system established from the 1994 tax reform. The upper level governments have got the more stable and lucrative taxes while the lower level governments are poorly funded. Table 1 shows the revenue sharing scheme between the central and local Governments obtained from the published report of a western city in China.

Table 1. Revenue sharing scheme between the central and local governments

\begin{tabular}{clccc}
\hline No. & Tax Items & Central Government & Provincial Government & City/Town Government \\
\hline 1 & Corporate Income Tax & $60 \%$ & $20 \%$ & $20 \%$ \\
2 & Personal Income tax & $60 \%$ & $20 \%$ & $20 \%$ \\
3 & Business Tax & & $100 \%$ & \\
4 & Municipal Construction Duties & $100 \%$ & $100 \%$ \\
5 & Stamp Duty & & $70 \%$ \\
6 & Town and Land Royalties & $30 \%$ & $70 \%$ \\
7 & Property Tax & $30 \%$ & \\
8 & Educational Expenses Add-on & $100 \%$ & \\
\hline
\end{tabular}

Note. The upper level governments have got more shares from the stable and lucrative taxes such as income tax.

With the rapid urbanization and local infrastructure development, local governments have a strong need to raise money, support and fuel the local economic growth. When the fiscal incomes mainly from the tax revenue are not enough to cover the expenses, the local governments have to borrow. However, according to the law in China, only central government can issue bonds; local governments are not allowed to borrow from the public directly. To resolve the funding problem for regional development, local governments have borrowed through the so-called shadow banks or agencies, such as state-owned enterprises (SOEs) and government controlled financial institutions. Such practice has escalated recently and led to an enormous debt with little transparency. For this reason, the national audit office conducted two nation-wide audits of government debt, in 2011 and 2013.

Figure 2 illustrates the official results for 2011 Year End and June of 2013. According to the national audit office, 
there are three types of government debt, which include: 1) public holdings of debt directly owed by governments, 2) debt guaranteed by governments and 3) governments' contingent liabilities. For example, the 2295.0 billion RMB debt owned by the China Railway Corporation (CRC) belongs to category 3, which means the central government is liable if CRC can't pay its loan on time.

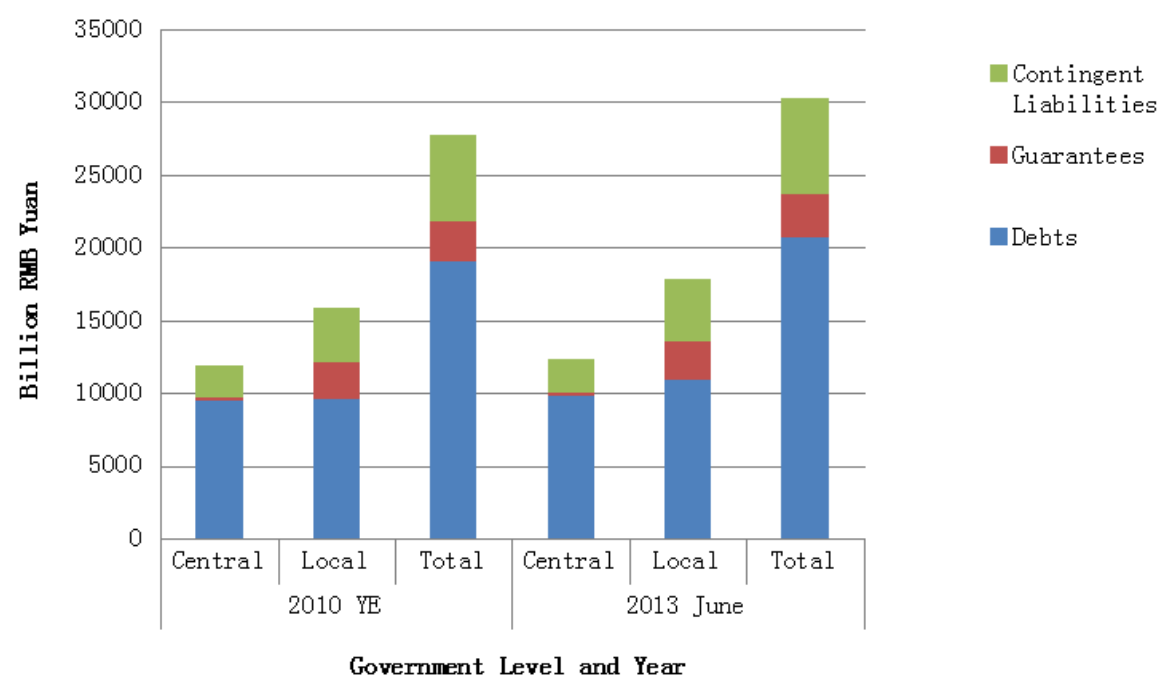

Figure 2. Government debt compositions from the national audits

Note. The national audit office lists three types of government debt and the changes from 2010 to 2013.

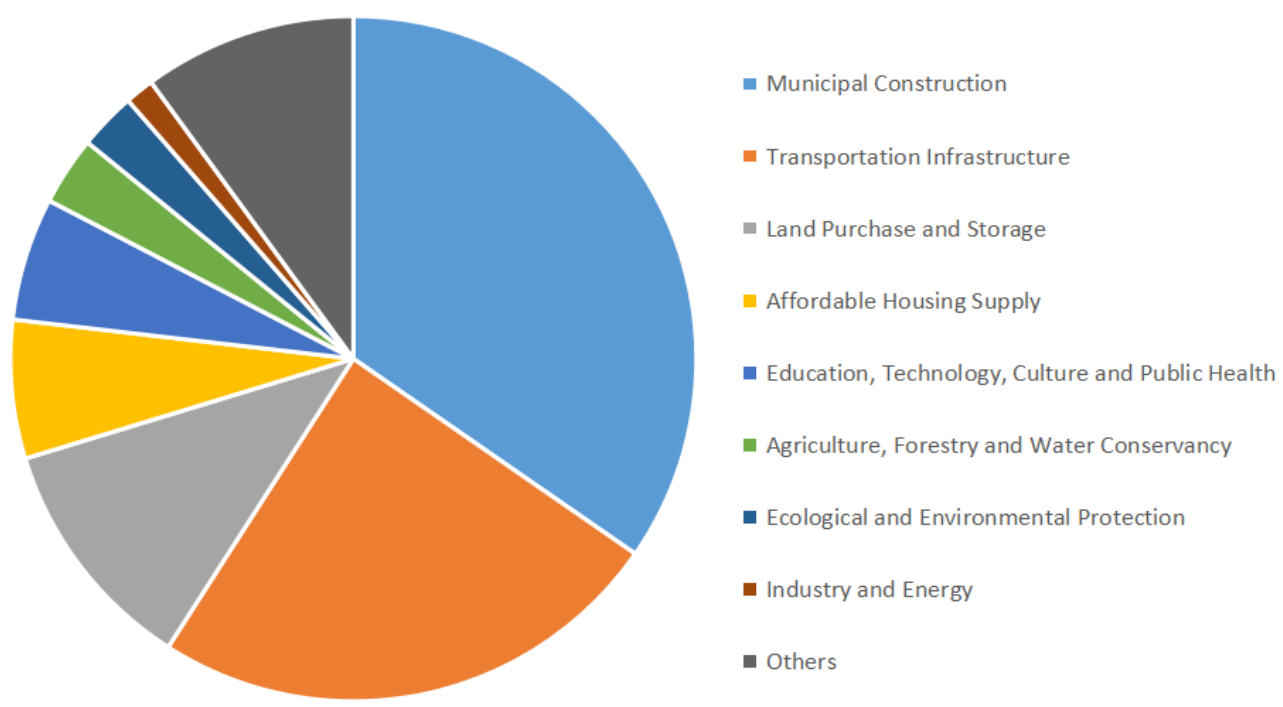

Figure 3. Type of government spending from LGD

Note. The national audit office finds most of the government debts are used for economic development.

Figure 3 shows the type of spending from the local government debts. According to the national audit conducted on 2013, over 70\% of the LGDs are spent on municipal construction, transportation Infrastructure, land purchase and storage. It indicates that the majority of the LGDs are used for local economic development activities.

To find out the relationships between government debt (referred as Debt), fiscal income (referred as Income), fiscal expense (referred as Expense), GDP and interest rate (referred as R), we assume that the change of government debt is the net difference of fiscal income and fiscal expense after the payout of interest on existing debt, as described below:

$$
\frac{d \operatorname{Debt}(t)}{d t}=-[\text { Income }(t)-\text { Expense }(t)-\operatorname{Debt}(t) * R(t)]
$$

If $\mathrm{Y}$ is used to represent the yield, and $\mathrm{P}$ stands for the Price, then 


$$
G D P(t)=Y(t) * P(t)
$$

If we use DR to represent the ratio of government debt to GDP, then

$$
\frac{\mathrm{d} D R(t)}{d t}=\frac{\mathrm{d}[\operatorname{Debt}(t) / G D P(t)]}{d t}=\left\{\frac{d \operatorname{Debt}(t)}{G D P(t)}-\frac{\operatorname{Debt}(t)}{G D P(t)}\left[\frac{d Y(t)}{Y(t)}+\frac{d P(t)}{P(t)}\right]\right\} / d t
$$

we plug in equation (1) into (3), and it becomes

$$
\frac{\mathrm{d} D R(t)}{d t}=\mathrm{FR}(\mathrm{t})-[\mathrm{YR}(\mathrm{t})+\operatorname{IR}(\mathrm{t})-\mathrm{R}(\mathrm{t})]^{*} \mathrm{DR}(\mathrm{t})
$$

in which we have defined the following variables:

$$
\begin{array}{lll} 
& \text { Debt-to-GDP ratio: } & \operatorname{DR}(\mathrm{t})=\operatorname{Debt}(\mathrm{t}) / \mathrm{GDP}(\mathrm{t}) \\
\text { Economic growth ratio: } & \mathrm{YR}(\mathrm{t})=\mathrm{dY}(\mathrm{t}) / \mathrm{Y}(\mathrm{t}) \\
\text { Inflation rate: } & \operatorname{IR}(\mathrm{t})=\mathrm{dP}(\mathrm{t}) / \mathrm{P}(\mathrm{t}) \\
\text { Fiscal deficit ratio: } & \mathrm{FR}(\mathrm{t})=[\text { Expense }(\mathrm{t}) \text {-Income }(\mathrm{t})] / \mathrm{GDP}(\mathrm{t})
\end{array}
$$

If we assume the four ratios including YR, IR, FR and $\mathrm{R}$ are constant over a short period of time, then Equation (4) is a first order differential equation on $\mathrm{DR}(\mathrm{t})$. The solution is

$$
D R(t)=\frac{F R}{Y R+I R-R}+c e^{-(Y R+I R-R) t}
$$

in which, c can be any constant.

This means that the government debt will converge if the sum of economic growth rate and inflation rate is higher than the interest rate; otherwise, the government debt will grow out of control.

To further analyze the data, the natural logarithm system is used to model the relationship between local government debt, GDP and national financial income in this paper. The Consumer Price Index is introduced to reflect the impact of consumer price fluctuations. The higher consumer price will discourage the spending, and may impact government spending and debt level.

Hence the following auto-regressive linear equation is constructed:

$$
\operatorname{Ln}\left(\text { Debt }_{t}\right)=k_{0}+k_{l}\left(\text { GDPGrowth }_{t}\right)+k_{2} \operatorname{Ln}_{\left(\text {Income }_{t}\right)}+k_{3}\left(C P I_{t}\right)+u_{t}
$$

Here are the description of variables:

Debt: Local government debt (trillion RMB Yuan) in period $t$.

GDPGrowth: Gross Domestic Product growth rate (\%) in period t.

Income: National fiscal income (trillion RMB Yuan) in period $t$.

CPI: Consumer Price Index (\%) in period t.

The data for the variables listed is collected from China Economics and Social Development Statistics database. Among them, the local government debt is estimated by summing up the data reported from individual local governments. The GDP growth rate, national fiscal income and CPI are obtained directly from the database.

Table 2. Government debt, fiscal income, CPI and GDP growth rate values in China

\begin{tabular}{ccccc}
\hline Year & Government Debt (bln RMB) & Fiscal Income (bln RMB) & CPI & GDP Growth (\%) \\
\hline 1996 & 239.94 & 740.80 & 108.8 & 10.0 \\
1997 & 299.49 & 865.11 & 103.1 & 9.3 \\
1998 & 443.84 & 987.60 & 99.4 & 7.8 \\
1999 & 591.73 & 1144.41 & 98.7 & 7.6 \\
2000 & 788.89 & 1339.52 & 100.8 & 8.4 \\
2001 & 1051.75 & 1638.60 & 100.7 & 8.3 \\
2002 & 1402.18 & 1890.36 & 99.0 & 9.1 \\
2003 & 1771.23 & 2171.53 & 100.9 & 10.0 \\
2004 & 2237.42 & 2639.65 & 103.3 & 10.1 \\
2005 & 2826.31 & 3164.93 & 101.6 & 11.3 \\
2006 & 3570.2 & 3876.02 & 101.5 & 12.7 \\
\hline
\end{tabular}




\begin{tabular}{lcccc}
\hline 2007 & 4509.83 & 5132.18 & 104.5 & 14.2 \\
2008 & 5568.74 & 6133.04 & 105.6 & 9.6 \\
2009 & 9016.9 & 6851.83 & 99.1 & 9.2 \\
2010 & 10717.5 & 8310.15 & 103.2 & 10.4 \\
2011 & 10717.5 & 10387.44 & 105.4 & 9.3 \\
2012 & 15885.83 & 11725.35 & 102.6 & 7.7 \\
\hline
\end{tabular}

Source: China Economics and Social Development Statistics database.

\section{Results and Analysis}

Based on the time series data above, Augmented Dickey-Fuller unit root testing (ADF) is conducted to verify the stability of the time series. Table 3 shows that for variable $\operatorname{Ln}$ (Debt), $\operatorname{Ln}$ (GDPGrowth), $\operatorname{Ln}$ (Income) and CPI, the critical value of unit root test statistics at $1 \%, 5 \%$, and $10 \%$ significance levels are less than the value of T-statistic, and therefore the null hypothesis cannot be rejected, namely variable $\operatorname{Ln}(\mathrm{Debt}), \operatorname{Ln}(\mathrm{GDP})$, $\mathrm{Ln}$ (Income), CPI are non-stationary series. For each variable in the first order difference, the critical value of unit root test statistics are greater than the value of T-statistic. Hence after the first order difference, the time series of delta $\operatorname{Ln}($ Debt), delta $\operatorname{Ln}$ (GDPGrowth), delta $\operatorname{Ln}($ Income) and delta CPI are stable with the same integration order level, which meets the co-integration test requirement.

Table 3. ADF unit root testing result

\begin{tabular}{ccccccc}
\hline Variable & T-statistic & $1 \%$ level & $5 \%$ level & $10 \%$ level & Stable? & Integration order \\
\hline Ln(Debt) & -1.225219 & -3.920350 & -3.065585 & -2.673459 & No & 1 st order \\
$\triangle$ Ln(Debt) & -4.264533 & -3.959148 & -3.081002 & -2.681330 & Yes & \\
GDPGrowth & -1.635215 & -3.9203495 & -3.065585 & -2.673459 & No & 1 st order \\
$\triangle$ GDPGrowth & -3.164997 & -3.959148 & -3.081002 & -2.681330 & Yes & \\
Ln(Income) & 0.770552 & -3.920350 & -3.065585 & -2.673459 & No & 1 st order \\
$\triangle$ Ln(Income $)$ & -3.626722 & -4.004425 & -3.098896 & -2.690439 & Yes & \multirow{2}{*}{ 1st order } \\
CPI & -1.488997 & -4.004425 & -3.098896 & -2.690439 & No & \\
$\triangle$ CPI & -4.055509 & -3.769597 & -3.004861 & -2.642242 & Yes & \\
\hline
\end{tabular}

Next, the residual $\left(e_{t}\right)$ is inspected according to the estimation results and the residual time series. Table 4 displays the result of Augmented Dickey-Fuller unit root testing on the residual $\mathrm{e}_{\mathrm{t}}$.

Table 4. Residual testing result

\begin{tabular}{cccccc}
\hline Residual & T-statistic & $1 \%$ level & $5 \%$ level & $10 \%$ level & Stable? \\
\hline $\mathrm{e}_{\mathrm{t}}$ & -3.064736 & -3.959148 & -3.081002 & -2.681330 & Yes \\
\hline
\end{tabular}

As the T-statistic value of -3.064736 is close to or less than the critical value of unit root test statistics at $5 \%$ and $10 \%$ significance levels, the residual (et) is considered as a stationary series. The results show that during the period from 1996 to 2012, Ln(Debt) has co-integration relationship with GDPGrowth, Ln(Income) and CPI with the co-integration vector of $(0.015,1.48,-0.041)$. Thus there is a long-term equilibrium relationship between Ln(Debt), GDPGrowth, Ln(Income) and CPI.

Eviews software is used to perform the analysis using the ordinary least square method. The table listed below shows the calculated result. From the R square value (0.995) and F statistics (892.27), we can see the estimated equation is pretty good.

Table 5. Regression calculation result

\begin{tabular}{ccccc}
\hline Variable & Coefficient & Std. Error & T-statistic & Prob. \\
\hline GDPGrowth & 0.014829 & 0.015979 & 0.928025 & 0.3703 \\
$\ln ($ Income) & 1.480163 & 0.029539 & 50.10902 & 0.0000 \\
CPI & -0.041366 & 0.010002 & -4.135664 & 0.0012 \\
u & -0.004512 & 0.983987 & -0.004585 & 0.9964 \\
\hline
\end{tabular}


To further analyze the cause-effect relationship between the variables of $\operatorname{Ln}(\mathrm{Debt})$, GDPGrowth, $\mathrm{Ln}(\mathrm{Income})$ and CPI, the granger causality test is performed with Eviews and here is the result:

Table 6. Granger causality test result

\begin{tabular}{lccc}
\hline \multicolumn{1}{c}{ Null Hypothesis } & Year 1 & Year 2 & Year 3 \\
\hline GDPRATE does not Granger Cause & 0.5477 & 31.8717 & 14.3306 \\
LNDEBT & $(0.4724)$ & $(5 . \mathrm{E}-05)$ & $(0.0023)$ \\
LNDEBT does not Granger Cause & 0.0861 & 0.2989 & 0.1722 \\
GDPRATE & $(0.7738)$ & $(0.7480)$ & $(0.9118)$ \\
LNINCOME does not Granger Cause & 2.8966 & 4.6411 & 6.5641 \\
LNDEBT & $(0.1125)$ & $(0.0375)$ & $(0.0192)$ \\
LNDEBT does not Granger Cause & 3.4575 & 2.0294 & 0.4901 \\
LNINCOME & $(0.0857)$ & $(0.1821)$ & $(0.7001)$ \\
CPI does not Granger Cause LNDEBT & 0.3487 & 3.2122 & 3.4135 \\
& $(0.5650)$ & $(0.0837)$ & $(0.0820)$ \\
LNDEBT does not Granger Cause CPI & 4.8442 & 3.8409 & 8.3795 \\
& $(0.0464)$ & $(0.0579)$ & $(0.0102)$ \\
\hline
\end{tabular}

Note. p-values in parentheses.

From the result, it's clear that at Year 1 the null hypothesis is not rejected, but from Year 2 and 3 the null hypothesis is rejected. The probabilities that the GDP growth rate doesn't granger cause Debt, and the Income doesn't granger cause Debt are both below 5\%, hence the GDP growth rate and Income at the Year 2 and 3 is considered as the granger cause for Debt; similarly the Debt doesn't granger cause CPI are both below 5\% at Year 4, hence Debt is the granger cause for CPI at Year 3.

\section{Discussion}

From the above equation, it's interesting to find that the government debt level grows as the fiscal income and GDP growth rate increase. We assume that local government officials are motivated to drive economic growth. The result implies that local government with higher GDP growth rate and increased fiscal income will raise more debt. This explains that the local government have leveraged the debt for more economic growth. It's also interesting to find that CPI has a negative impact on the local government debt. When CPI increases, the cost to pay back the debts also increases, the local government tend to raise less debts to reduce the fiscal risks.

In the last couple of years, China has entered the new normal development stage of slower growth and structural change after three decades of rapid growth. This is an opportunity for China to adjust the growth rate for a better quality. It's projected that the economy is continue growing steadily and at a bit slower pace (GDP growth rate was reported at 7.7 per cent in 2013, 7.4 per cent in 2014 and 6.9 per cent in 2015). From the calculated result above, slower growth and less income with a stable CPI would lead to slower accumulation of debt levels. Hence we think the debt reduction goal and quality growth at a slower pace is achievable as China transits into the new normal stage, which is helpful to slow down local government debt accumulation though it's difficult to reverse the trend of debt increase in short time.

To avoid a hard landing, the government needs to set up an alarm system that monitors the debt default risk from time to time by collecting various economic data and analyzing their combined impact to the debt pay back capabilities of all levels of government. To increase the transparency of financial data, one suggestion is to allow local governments to issue bonds directly, which will help reduce the risks from uncertainty. Actually in 2014, ten provinces and municipalities (Beijing, Jiangsu, Shanghai, Shenzhen, Guangdong, Zhejiang, Jiangxi, Shandong, Ningxia and Qingdao) received approval from the Ministry of Finance to issue local government bonds. This represents a major change in public finance and governance and may have implications for regional economic development in China. In addition, it's been suggested to add debt reduction progress as part of the performance evaluation matrix along with the economic development and environment protection for local government official promotion. With the risks identified and quantified, the government should use tools to mitigate risk such as setting the debt limit, building the buffers and mechanisms to transfer risks. This may help reverse the trend of debt accumulation from the management level. Finally, the reform of tax revenues system with the re-balanced responsibilities and ownership between central and local governments can significantly change the way local government finance regional economic development activities, and may resolve the local 
debt issues ultimately for a more balanced sustainable economic development.

As the world's second largest economy, China has seen its economy go through an immense restructure and transition over the past years to a new era of slower, more sustainable growth driven by service and consumption, which has become known as "the new normal". Chinese government has begun to take serious measures such as promoting thrifty with reduced spending budget, and eliminating debts aggressively on a pre-set schedule. It's reasonable to state that the current debt level in China is manageable though caution and close monitoring on the status should be remained in the coming years. From the calculated result, it's shown that slower growth and less income with a stable CPI would lead to smaller accumulation of government debts. The risk of a debt crisis in China is considered to be moderate. The Chinese government should monitor the risk factors closely and use risk mitigation tools wisely to avoid a hard landing.

\section{Acknowledgments}

The paper was partly funded by the world bank research grant ID1.2-1A1 (Study on the Local Government Debt of Xi'an City: Assessment, Warning and Control).

The authors would like to thank Prof. Ali Kutan from Southern Illinois University, Mark Kruger from Bank of Canada, and Wang Xinmei from the China Academy of Social Science for their kind advice while participating in the International Conference on Institutions Reforms And Economic Development in Beijing, China.

Finally we'd like to pay tribute to the editors and anonymous reviewers for their professional input.

\section{References}

Afonso, A., João, T. Jalles. (2013). Growth and Productivity: The Role of Government Debt. International Review of Economics and Finance, 25(C), 384-407. https://doi.org/10.1016/j.iref.2012.07.004

Akai, N., \& Sato, M. (2011). A Simple Dynamic Decentralized Leadership Model with Private Savings and Local Borrowing Regulation. Journal of Urban Economics, 70(1), 15-24. https://doi.org/10.1016/j.jue.2011.02.002

António, A., Michael, G. A., \& Alexandros, K. (2014). Pricing Sovereign Bond Risk In The European Monetary Union Area: An Empirical Investigation. International Journal of Finance \& Economics, 19(1), 49-56. https://doi.org/10.1002/ijfe.1484

Atish, R. G., Jun, I. K., Enrique, G. M., Jonathan, D. O., \& Mahvash, S. Q. (2013). Fiscal Fatigue, Fiscal Space and Debt Sustainability in Advanced Economies. Royal Economic Society, F4-F30, 02.

Balázs, É. (2013). The 90\% Public Debt Threshold: The Rise and Fall of a Stylized Fact. OECD Economics Department Working Papers 1055, OECD Publishing.

Baum, A., Checherita-Westphal, C., \& Rother, P. (2013). Debt and Growth: New Evidence from the Euro Area. Journal of International Money and Finance, 32, 809-821. https://doi.org/10.1016/j.jimonfin.2012.07.004

Cai, H., \&Treisman, D. (2005). Does Competition for Capital Discipline Governments? Decentralization, Globalization, and Public Policy. American Economic Review, 95(3), 817-830. https://doi.org/10.1257/0002828054201314

Catherine, P., Hélène, P., \& Luca, A. R. (2011). External Debt and Growth. Review of Economics and Institutions, 2(3).

Cecchetti, S. G., Mohanty, M. S., \& Zampolli, F. (2011). Achieving growth amid fiscal imbalances: The real effects of debt. Proceedings - Economic Policy Symposium - Jackson Hole, 2011, Federal Reserve Bank of Kansas City, pp. 145-196.

Checherita-Westphal, C., \& Rother, P. (2012). The impact of high government debt on economic growth and its channels: An empirical investigation for the euro area. European Economic Review, 56(7), 1392-1405. https://doi.org/10.1016/j.euroecorev.2012.06.007

Cline, W. R., (2005). The United States as a Debtor Nation. Institute for International Economics Center for Global Development, Washington, DC, September 2005.

Cochrane, J. H. (2011). Understanding policy in the great recession: Some unpleasant fiscal arithmetic. European Economic Review, 55(1), 2-30. https://doi.org/10.1016/j.euroecorev.2010.11.002

Cordella, T., Luca, A. R., \& Marta, R. (2005). Debt Overhang or Debt Irrelevance? Re-visiting the Debt-Growth Link. IMF Working Paper, 2005, 05/233.

Diamond, P. A. (1965). National Debt in a Neoclassical Growth Model. American Economic Review, 55(5), 
$1126-1150$.

Emgle, R. F., \& Granger, C. (1987). Co-integration and Error Correction: Representation, Estimation, and Testing. Econometrica, 55, 251-276. https://doi.org/10.2307/1913236

Faraglia, E., Marcet, A., \& Scott, A. (2010). In Search of a Theory of Debt Management. Journal of Monetary Economics, 57(7), 821-836. https://doi.org/10.1016/j.jmoneco.2010.08.005

Furceri, D., \& Zdzienicka, A. (2012). How costly are debt crises? Journal of International Money and Finance, 31(4), 726-742. https://doi.org/10.1016/j.jimonfin.2012.01.012

Handerson, J. V., \& Thisse, J. F. (2001). On Strategic Community Development. Journal of Political Economy, 109(3), 546-568. https://doi.org/10.1086/321017

Hidreth, W. B., \& Miller, G. J. (2002). Debt and Local Economy: Problems in Bench-marking Local Government Debt Affordability. Public Budgeting and Finance, (4).

Irons, J., \& Josh, B. (2010). Government Debt and Economic Growth. EPI Briefing Paper, Economic Policy Institute, Jul. 26, 2010.

Jianyong, F., \& Jiawei, M. (2014). Analysis of Local Debts, "Land Supply and Local Industrial Growth". Economic Research, 1, 41-55.

Kourtellos, A., Stengos, T., \& Tan, C. M. (2013). The effect of public debt on growth in multiple regimes. Journal of Macroeconomics, 38(PA), 35-43. https://doi.org/10.1016/j.jmacro.2013.08.023

Kumar, M., \& Woo, J. (2010). Public Debt and Growth. IMF Working Paper, 2010, No. 10/174, pp. 1-47.

Li, Y., Zhang, X. etc. (2015). China's national balance sheet 2015: Leverage adjustment and risk management. Chinese Academy of Social Science Press, July 2015.

National Audit Office. (2011). Local Government Debt Audit Result in China, 2011, Pub. 35. Retrieved from http://www.audit.gov.cn/n1992130/n1992150/n1992500/2752208.html.

National Audit Office. (2013). Local Government Debt Audit Result of 36 Cities, 2013, Pub. 24. Retrieved from http://www.audit.gov.cn/n1992130/n1992150/n1992500/3291665.html.

National Audit Office. (2013). Local Government Debt Audit Result in China, 2013, Pub. 32. Retrieved from http://www.audit.gov.cn/n1992130/n1992150/n1992500/3432077.html

Pescatori, A., Sandri, D., \& Simon, J. (2014). Debt and Growth: Is There a Magic Threshold? IMF Working Paper No. 14/34, Washington DC.

Qiang, G., Jun, W., \& Shen, J. (n. d.). Study on the Local Government Debt from the Fiscal Decentralization Perspective: An Overview. Economic Research (China), 7.

Reinhart, C. M., \& Rogeoff, K. (2010). Growth in a Time of Debt. American Economic Review, 100(2), 573-578. https://doi.org/10.1257/aer.100.2.573

Reinhart, C. M., Reinhart, V. R., \& Rogoff, K. S. (2012). Public Debt Overhangs: Advanced-Economy Episodes Since 1800. Journal of Economic Perspective, 26(3), 69-86. https://doi.org/10.1257/jep.26.3.69

Rubin, R. E., Orszag, P. R., \& Sinai, A. (2004). Sustained Budget Deficits: Longer-Run U. S. Economic Performance and the Risk of Financial and Fiscal Disarray. Allied Social Science Associations Annual Meetings, The Andrew Brimmer Policy Forum: National Economic and Financial Policies for Growth and Stability, January 4, 2004, San Diego, CA.

Teles, V. K., \& Cesar, M. C. (2014). Public debt and the limits of fiscal policy to increase economic growth. European Economic Review, 66(C), 1-15. https://doi.org/10.1016/j.euroecorev.2013.11.003

Ugo, P., \& Andrea, F. P. (2013). Public Debt and Economic Growth in Advanced Economies: A Survey. Swiss Journal of Economics and Statistics (SJES), 149(II), 175-204.

World Bank Urbanization and Land Regulation Reform Council. (2005). Urbanization, Land Regulation and Sustainable Economic Development: How Long can It Last for the Land-based Urbanization. World Bank.

Wu, Y. (2014). Local government debt and economic growth in China. BOFIT Discussion Papers, Helsinki. https://doi.org/10.2139/ssrn.2537409

Xu, J., \& Zhang, X. (2013). The Current Status, Sourcing and Risk Analysis of Government Debt in China. Southern China Economy (China), 1. 
Yanfen, W. (2016). IMF senior official says restructuring is essential for country to avoid debt crisis. China Daily, Business and Economics Section, 2016/09/27.

Zhou, M., \& Wang, M. (2016). Perspectives on FDI, Debt and Economic Growth in Emerging Markets: Evidence from China. International Journal of Trade, Economics and Finance, 7(4), 148-52.

\section{Copyrights}

Copyright for this article is retained by the author(s), with first publication rights granted to the journal.

This is an open-access article distributed under the terms and conditions of the Creative Commons Attribution license (http://creativecommons.org/licenses/by/4.0/). 